\title{
THE EDUCATIONAL MODELS IN AIR FORCE PERSONNEL TRAINING PROCESS
}

\author{
Volodymyr POLISHCHUK ${ }^{1}$, Stanislav ĎURČO ${ }^{2}{ }_{\text {Branko MIKULA }}^{2}$, Róbert ROZENBERG ${ }^{2 *}$, \\ Peter KALAVSKÝ ${ }^{2}$, Dorota LIPTÁKOVÁ ${ }^{2}$ \\ ${ }^{1}$ Faculty of Information Technologies, Uzhhorod National University, Uzhhorod 88000, Ukraine \\ ${ }^{2}$ Faculty of Aeronautics, Technical University of Košice, Rampová 7, 04121 Košice, Slovakia \\ *Corresponding author. E-mail: robert.rozenberg@tuke.sk
}

\begin{abstract}
This study deals with the project research titled "The Educational models for Air Force Personnel training process", ordered by the Air Force of the Slovak Armed Forces. The research is focused on analyses and evaluation of theoretical and practical part of military pilots trainings at the Faculty of Aeronautics in the past and comparing with existing educational processes. The research unveils strengths and weaknesses of the educational programmes through the history of the faculty, since established as the University of Air Force at Kosice till its present status.
\end{abstract}

Keywords: military pilot; educational process; theoretical preparation; threats; opportunities

\section{INTRODUCTION}

The project "The Educational models for Air Force Personnel training process" is staffed by a team of employees of the Department of Flight Preparation at the Faculty of Aeronautics. An objective of the research is defined as the opportunity to confirm or disprove a feasibility of those educational processes for the Air Force of the Slovak Republic. The study consists of analyses of educational processes of professional personnel in the past and present in Slovakia and an evaluation of the same process abroad. The study should identify current interests and demands of the Air Force of the Slovak Republic for training of professional air force personnel prior to their appointment to a military role as well as their continuing educational and training process. The proposed part of the study of the feasibility includes defined models of educational process for professional personnel at the Air Force of the Slovak Republic. The proposed models for the educational programme of military personnel truly and reasonably empowers disclosure of programme's strengths and weaknesses, their opportunities and threats, time indicators as well as sources necessary for their operational introduction. The Models for educational processes of professional personnel in services of the Air Force of the Slovak Republic are dedicated for professional tactical flight pilots, professional helicopter pilots, professional commercial pilots, professional air traffic controllers and professional air service engineers. The study consists of analyses and evaluation of flight preparation studies and flight trainings of future pilots, while comparing the past years and current situation by forming an overview on theoretical and practical pilots training throughout the defined time line, since early years until present times. Also, the study assesses used methods and forms of training process for military pilots as well as didactic and material tools implemented to this teaching programmes. The study applies various methods to compare strengths and weakness of the processes and describing opportunities and threats in military pilots educational system $[1-4,16-$ $18]$. 


\section{THE ANALYSES AND EVALUATION OF THEORETICAL AND PRACTICAL TRAINING OF MILITARY PILOTS IN THE PAST}

A significant part of theoretical studies and parallel training for military airplane and helicopter pilots was organized on university level at VVL ̌̌-VKA. The practical flights were performed at subsidiary Air Force commands in Košice, Přerov and Pieštany. The flight preparation theoretical training and practical training for military transport airplane pilots followed a demand made from military air transport headquarters. The selection process for new pilots positions was focused on university students completing their last studying year. Or this process was organized as a retraining existing pilots already assigned at military divisions. Regarding students training, this was designed according approved educational programme following a scheme of air military transport educational system for selected aircraft types and technical equipment located at bases in Piešt’any, Malacky, Kbely and Mošnov [1-6, 9-12].

Between 1973 and 1990, the theoretical flight preparation training was organized as a standard 4 year learning programme titled "Pilot of fighter airplane". Between 1990 and 2004, this subject was scheduled as a 5-year study module titled "Pilot of fighter airplane". Between 2004 and 2020, this study programme was titled "Professional pilot". The educational plan has been outlined as a standard 3 -year bachelor study programme. Beyond 2020, this subject will continue as the study programme "Pilot" and scheduled as 3-year bachelor module.

Table 1 The comparison of course blocks in different study plans

\begin{tabular}{|l|c|c|c|c|}
\hline \multirow{2}{*}{ Course blocks } & \multicolumn{4}{c|}{ Study hours for mandatory courses } \\
\cline { 2 - 5 } & \multicolumn{4}{c|}{ Period } \\
\cline { 2 - 5 } & $\begin{array}{c}\mathbf{1 9 7 3 -} \\
\mathbf{1 9 9 0}\end{array}$ & $\begin{array}{c}\mathbf{1 9 9 0 -} \\
\mathbf{2 0 0 4}\end{array}$ & $\begin{array}{c}\mathbf{2 0 0 4}- \\
\mathbf{2 0 2 0}\end{array}$ & $\begin{array}{c}\mathbf{2 0 2 0}- \\
\mathbf{2 0 2 5}\end{array}$ \\
\hline $\begin{array}{l}\text { Mathematical - physical and theoretical } \\
\text { essentials }\end{array}$ & 490 & 380 & 208 & 253 \\
\hline $\begin{array}{l}\text { Basic professional and transport means } \\
\text { subjects }\end{array}$ & 640 & 1300 & 923 & 539 \\
\hline Physical education & 200 & 378 & 104 & 44 \\
\hline English language & 0 & 500 & 234 & 22 \\
\hline $\begin{array}{l}\text { Flight training and flight-methodical } \\
\text { preparation }\end{array}$ & 1500 & 1512 & 1100 & 1100 \\
\hline
\end{tabular}

Table 2 The comparison of percentage shares of course blocks in study plans

\begin{tabular}{|l|c|c|c|c|}
\hline \multirow{2}{*}{\multicolumn{1}{|c|}{ Course blocks }} & \multicolumn{4}{c|}{ Percentage share of mandatory subjects } \\
\cline { 2 - 5 } & \multicolumn{4}{c|}{ Period } \\
\cline { 2 - 5 } & $\begin{array}{c}\mathbf{1 9 7 3 -} \\
\mathbf{1 9 9 0}\end{array}$ & $\begin{array}{c}\mathbf{1 9 9 0 -} \\
\mathbf{2 0 0 4}\end{array}$ & $\begin{array}{c}\mathbf{2 0 0 4}- \\
\mathbf{2 0 2 0}\end{array}$ & $\begin{array}{c}\mathbf{2 0 2 0}- \\
\mathbf{2 0 2 5}\end{array}$ \\
\hline $\begin{array}{l}\text { Mathematical - physical and theoretical } \\
\text { essentials }\end{array}$ & 20 & 6 & 7 & 11 \\
\hline $\begin{array}{l}\text { Basic professional and transport means } \\
\text { subjects }\end{array}$ & 18 & 21 & 30 & 24 \\
\hline Physical education & 6 & 6 & 3 & 2 \\
\hline English language & 0 & 8 & 8 & 2 \\
\hline $\begin{array}{l}\text { Flight training and flight-methodical } \\
\text { preparation }\end{array}$ & 41 & 25 & 36 & 50 \\
\hline
\end{tabular}




\section{METHODS AND FORMS OF EDUCATIONAL PROCESSES FOR MILITARY PILOTS}

The majority of educational methods at VVLŠS-VLA were organized as a mixture of oral methods and practical ones, for example a training of piloting skills in a simulator environment. The study programme was based on methods of pilot students motivation plus fixation teaching methods including frequent study task repetitions and firm memorization of essential knowledge necessary for a real time flying. Obviously, VVLŠS-VLA's educational process failed to implement the troubleshooting teaching methods. Regarding diagnostic and evaluation methods, the process applied oral exams and writing tests including practical tests on a simulator.

After this educational institution had been reorganized and established as The Faculty of Aeronautics, the majority of teaching methods were oral, however, enhanced by troubleshooting methods. Students were becoming active members of faculty project teams and research programmes. Anyway, the basic educational method still remains practical pilot training on simulators. The simulator training is included in two subjects "Flight Simulator Practical Training part I, II, III" and "Flight Planning and Monitoring" [7-8, 13-15].

Today's study programmes are based on the motivation of pilot students which has been included into each course. Also the Faculty used to organize a plenty of professional seminars with invited expert speakers to present $\mathrm{n}$ the students their broad practical experience. The troubleshooting methods are included in students' current paper works, final paper works as well as students participation at the Student Scientific Research Programme.

\section{THE COMPARISON OF CURRENT AND FORMER EDUCATIONAL PROCESSES FOR MILITARY PILOTS AT THE FACULTY OF AERONAUTICS}

The comparison of the educational processes was organized into three consecutive periods:

I. 1973-1990, VVLŠ (University of Military Aeronautics) established

II. 1990-2004, VVLŠ (University of Military Aeronautics) transformed onto the Faculty of Aeronautics established

III. 2004 - to date

Each period of this educational establishment has its typical characteristics with strengths and weaknesses, opportunities and threats. The term "threats" was understood as specific physical and existing subjects, events, situations or occurrences with potential to incur damage or loss.

The process of threats identification consists of locating possible unwanted negative circumstances and occurrences that could exist in various forms and aspects throughout the educational process, and might be of a threat to the achievement of processes' objectives.

The purpose of the threats identification, is detection of all significant threat categories, sources allocation, impact on educational process, definition of motives, plans, causality and analyses of current and past frequency of their appearance. The threats identification per a period is discussed in the TAB.3.

Table 3 Threats identification throughout the periods

\begin{tabular}{|c|c|}
\hline Period & Threats \\
\hline $1973-1990$ & $\begin{array}{l}\text { - limited group of applicants for a position of a military pilot with satisfying } \\
\text { health conditions } \\
\text { - } \text { limited applicants' chances for a university study due strict and conditions } \\
\text { established by the Communist Party of Czechoslovakia } \\
\text { - very limited cooperation with non-military educational establishments as well } \\
\text { as international ones } \\
\text { - limited competency to release students not reaching set knowledge standards } \\
\text { - excessive and obligatory planning of Marxism-Leninism subjects into the } \\
\text { educational process what made the whole studying programme unbalanced }\end{array}$ \\
\hline
\end{tabular}




\begin{tabular}{|c|c|}
\hline $1990-2004$ & 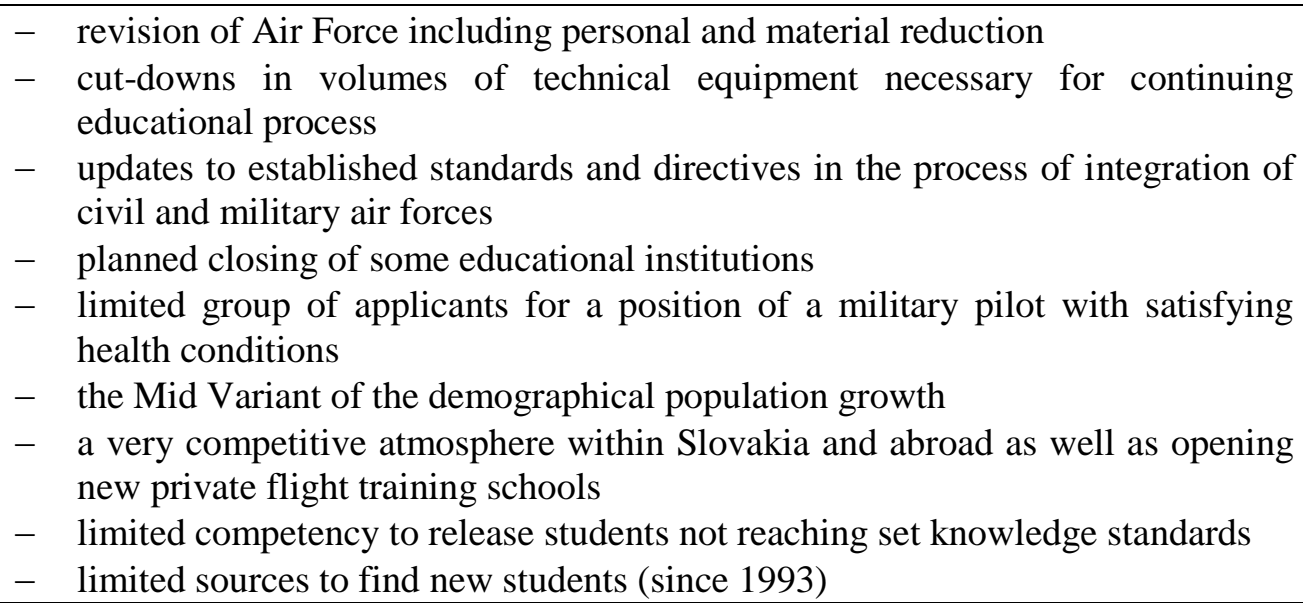 \\
\hline $2004-2019$ & $\begin{array}{l}\text { - only average knowledge and creative potentials of some new enrolled students } \\
\text { for the military study programmes } \\
\text { - } \text { limited group of applicants for a position of a military pilot with satisfying } \\
\text { health conditions } \\
\text { - } \text { reductions and organizational changes in Air Force in Slovakia } \\
\text { - cut-downs in volumes of technical equipment necessary for continuing } \\
\text { educational process } \\
\text { - } \text { the Mid Variant of the demographical population growth } \\
-\quad \text { a very competitive atmosphere within Slovakia and abroad as well as opening } \\
\text { new private flight training schools } \\
\text { - the state budget has an obsolete methodology of financial sponsoring to public } \\
\text { universities. } \\
-\quad \text { an evaluation process of university lectors does not reflect their quality of work } \\
\text { the system does not improve teaching effectivity, didactic and social } \\
\text { competencies of a lector }\end{array}$ \\
\hline
\end{tabular}

\section{CONCLUSION}

The Ministry of Defence of the Slovak Republic is considerably engaged with a task how to attract new enthusiastic and qualified young members to teams of armed forces. The Ministry has informed that thousands of military employees or let us say soldier positions are still unoccupied. There are various reasons on this occasion like declining interests in such service among young people community, unsatisfying qualitative skills and abilities of applicants as well as retirement and reserve replacement of existing military personnel.

This study of the feasibility of the models for educational process for personnel in The Air Force of the Slovak Republic contributes to an effective tool for managing future directions of the system and strategies designed for educational processes of professional air force personnel in the Slovak Republic.

\section{References}

[1] Opis projektu - Model prípravy odborného personálu pre potreby Vzdušných síl OS SR MOPODPER, Technická univerzita v Košiciach, Letecká fakulta, Zodpovedný riešitel': Dr.h.c., doc., Ing. Stanislav Szabo, PhD., MBA, LL.M.

[2] Kal'avský, P. \& et al. Human Factors and Analysis of Methods, Forms and Didactic Means of Aviation Education of Military Pilots. 2019. In: New Trends in Aviation Development 2019. Danvers (USA): IEEE, p. 77-81 [print]. ISBN 978-1-7281-4078-0 
[3] Kal'avský, P. \& et al. Identification of University Aviation Education Risks of Military. 2019. In: New Trends in Aviation Development 2019. Danvers (USA): Institute of Electrical and Electronics Engineers, 2019 s. 82-86. ISBN 978-1-7281-4078-0

[4] Ďurčo, S. \& et al Zvýšenie názornosti výučby predmetov letovej prípravy. 2017. In: Aplikace simulátorů ve výcviku leteckých specialistů. - Ostrava: LET'S FLY s.r.o., 2017 P. 374-380. ISBN 978-80-270-2104-8

[5] Koščák, P. \& Kolesár, J. Safety of Airport Operation. 2015. In: Aeronautica 15. - Lublin: Lublin University of Technology, 2015 P. 193-204. - ISBN 978-83-7947-149-2

[6] Koščák, P. \& et al. Automatizácia v prevádzke letísk. 2018. In: Bezpečnost' a doprava 2018: Teória a prax $\mathrm{v}$ bezpečnosti a krízovom riadení v doprave. Brno (Česko): Akademické nakladatelství CERM s. 11-21 [CD-ROM]. ISBN 978-80-7623-002-6

[7] Hrabčák, D. \& et al. Students Social Based Mobility Model for MANET-DTN Networks. 2017. In: Mobile Information Systems. Vol. 2017, doi.org/10.1155/2017/2714595 (2017), p. 1-13. ISSN 1574-017X

[8] Hrabčák, D. \& et al. Tools for evaluation of social relations in mobility models. 2018. In: Telecommunication systems. Vol. 68, no. 3 (2018), p. 409-424. - ISSN 1018-4864

[9] Makó, S. \& et al. Wizz air cabin crew training. 2018. In: CER Comparative European Research 2018: proceedings/research track. London (GB): Sciemcee Publishing, p. 30-33. ISBN 978-09935191-9-2

[10] Kršák, B. \& Tobisová, A. Prerequisites for the implementation of information technologies in tourism small and medium sized enterprises. 2012. In: SGEM 2012: 12th International Multidisciplinary Scientific GeoConference: conference proceedings: Volume 3: 17-23 June, 2012, Albena, Bulgaria. Sofia: STEF92 Technology Ltd., 2012 P. 205-212. ISSN 1314-2704

[11] Martonová, S. \& Tobisová, A. The education process in an aviation company. 2012. In: Acta Avionica. Roč. 14, č. 24 (2012), s. 275-278. - ISSN 1335-9479

[12] Spišáková, V. \& Tobisová, A. Human resources in the multicultural environment of the selected company. 2014. In: Acta Avionica. Roč. 16., č. 2 (2014), s. 1-3. - ISSN 1335-9479

[13] Bréda, R. Experimental measurement of parameters of the spatial scanner Hokuyo URG 04LX. 2012. In: Przegląd Elektrotechniczny: Electrical Review. Vol. 88, no. 5b (2012), p. $132-$ 136. - ISSN 0033-2097

[14] Bréda, R. \& et al. Robust controller in the structure of lateral control of maneuvering aircraft. 2013. In: Acta Polytechnica Hungarica. Vol. 10, no. 5 (2013), p. 101-124. - ISSN 1785-8860

[15] Andoga, R. \& et al. Intelligent Thermal Imaging-Based Diagnostics of Turbojet Engines. 2019. In: Applied Sciences. - Basel (Švajčiarsko): Multidisciplinary Digital Publishing Institute Roč. 9, č. 11 (2019), s. 1-22. - ISSN 2076-3417

[16] Galanda, J. \& et al. Virtual concept of a symbiotic environment for CBL and CBT methods based education in aircraft system. 2016. In: Nase More. Vol. 63, no. 3 (2016), p. 244- 248. ISSN 0469-6255

[17] Rozenberg, R. \& et al The training of civilian pilots in Slovakia. 2017. In: Aeronautika 17. Lublin: University College of Enterprise and Administration, 2017 P. 322-326. - ISBN 978-8360617-49-6

[18] Rozenberg, R. \& et al Human Factors and Analysis of Aviation Education Content of Military Pilots. 2019. In: New Trends in Aviation Development 2019. - Danvers (USA): Institute of Electrical and Electronics Engineers s. 77-85. - ISBN 978-1-7281-4078-0

Received 08,2019 accepted 12,2019

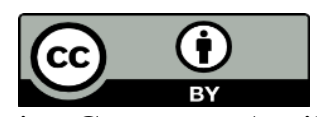

Article is licensed under a Creative Commons Attribution 4.0 International License 